\title{
Kaptein Vom - hadde han bare podagra?
}

\author{
Inntak av fruktose, men ikke glukose, stimulerer purinmetabolismen og produksjonen av urinsyre og øker \\ leverens produksjon av fettstoffer. Urinsyrenivået kan ha større betydning for utvikling av kardiovaskulær \\ sykdom enn hittil antatt. Bruk av fruktose som søtningsmiddel i ferdigprosessert mat har vært sterkt økende.
}

\section{Tor Erik Widerøe}

tor-erik.wideroe@ntnu.no

Institutt for kreftforskning og molekylærmedisin Det medisinske fakultet

Norges teknisk-naturvitenskapelige universitet 7491 Trondheim

Tegneserien Knoll og Tott med blant annet kaptein Vom ble laget av amerikaneren Rudolph Dirks (1877-1968). Serien startet i 1887 i søndagsmagasinet New York Journal og er den eldste tegneserien som fortsatt trykkes.

Hvorfor var kaptein Vom overvektig og hadde podagra? Fremtredende leger mente på 1800-tallet at podagra var assosiert med urinsyre i blodet (1), og at urinsyre kunne være en av flere årsaker til høyt blodtrykk (2). Kanskje var denne kunnskapen grunnleggende for fremstillingen av kaptein Vom? Likevel er ikke urinsyre omtalt som en risikofaktor av kausal betydning for kardiovaskulær sykdom i internasjonale behandlingsretningslinjer (3).

\section{Urinsyre - et tilbakeblikk}

En sammenheng mellom høye urinsyreverdier og kardiovaskulær sykdom, spesielt ved hypertensjon og metabolsk syndrom, har vært kjent lenge, men høye urinsyrekonsentrasjoner har stort sett vært vurdert som et sekundært fenomen uten kausal betydning. Ved asymptomatiske høye urinsyreverdier er det mange som har hypertensjon, overvekt, metabolsk syndrom, nyresykdom og kardiovaskulær sykdom. Ved podagra er mer enn $70 \%$ overvektige, over $50 \%$ har hypertensjon, nesten alle har nyresvikt, og om lag $90 \%$ utvikler hjerte- og karsykdom, hvorav om lag $20 \%$ dør av dette $(4,5)$.

For ca. 15 millioner år siden utviklet en av våre forfedre en mutasjon i genet for urokinase, et leverenzym som spalter urinsyre til allantoin som endeprodukt. Mennesker og store aper, slik som sjimpanser og gorillaer, har høyere urinsyrenivå i blodet enn laverestående pattedyr. Mennesker har nedsatt evne til å regulere konsentrasjonen av urinsyre utover den renale utskillingen $(6,7)$.

\section{Glukose og fruktose - et tilbakeblikk}

Dyrking av sukkerrør, som ga rørsukker, startet i New Guinea og India. Rørsukker kom via Venezia og andre havnebyer til Europa i middelalderen. Christopher Columbus brakte det til Haiti og den nye verden i 1493. Gjennom det 18. århundret økte produksjonen av sukker fra sukkerroer. Fra begge plantene utvinnes sukrose, et disakkarid som består av like deler glukose og fruktose, og som brukes som bordsukker i vanlig husholdning. Senere, ved spalting av stivelse til glukose (corn syrup), økte forbruket av sukker betydelig, spesielt som søtningsmiddel i ferdigprosessert mat.

I 1970 greide en japansk forskergruppe å spalte stivelse til både glukose og mer enn $50 \%$ fruktose (high fructose corn syrup, HFCS) (8). Dette var et gjennombrudd for tilsetting av sukker i prosessert mat og utgjør den største andelen av daglig inntatt fruktose i USA (9). I forhold til glukose er fruktose søtere, billigere, mer oppløselig ved lavere temperaturer og mer stabilt. Fruktsukker er i dag det mest brukte naturlige søtningsmidlet i mat og drikkevarer og er ansvarlig for mer enn $40 \%$ av kaloriske søtningsmidler tilsatt prosessert mat og drikkevarer. I perioden 1970-90 økte HFCSforbruket mer enn $1000 \%$, betydelig mer enn endret inntak av andre næringsmidler (10). I industrialiserte land er det en sammenheng mellom økt inntak av fruktsukker og økt forekomst av hypertensjon, overvekt, metabolsk syndrom, diabetes, nyresvikt og kardiovaskulær sykdom (9). Frukt og spesielt grønnsaker utgjør en liten del av det daglige inntaket av fruktsukker.

\section{Omsetning av fruktsukker}

I Norge har fruktsukker som næringsmiddel ikke vært omtalt av Statens næringsmiddelråd. Innholdet av fruktsukker i norske matvarer angis ikke, noe det heller ikke er krav om. Enkelte kostholdseksperter har anbefalt å erstatte glukose med fruktose, fordi fruktose angis å ikke stimulere insulinproduksjonen og har en lavere «glukoseindeks» med mindre fedmeutvikling som følge.

Fruktose absorberes uforandret i tynntarm, 50\% metaboliseres i lever, og resten tas opp av nyre og fettvev. Det transporteres intracellulært via transportproteinene GLUT-2 og GLUT-5. Begge disse proteinene finnes i endotelceller og i nyretubulusceller, spesielt i proksimale tubulus. Fruktose kan fosforyleres via heksokinase, men fortrenges av glukose, som har preferanse. Fosforyleringen skjer derfor via ketoheksokinase (fruktokinase). Fruktose passerer forbi alle glykolytiske kontrollposter. Passasjen via ketoheksokinase har ingen negativ tilbakekoblingsmekanisme, og fruktose blir fosforylert inntil adenosintrifosfat (ATP) er brukt opp. Som en reserveløsning blir enzymene i purinmetabolismen (xantinoksidoreduktaser) aktivert slik at produksjonen av endeproduktet urinsyre økes (11).

Urinsyre er en intracellulær oksidant, hemmer produksjonen av nitrittoksid og stimulerer monocyttkjemotaktisk protein-1 (MCP-1), et proinflammatorisk protein som gir fiboseutvikling i nyren (12). Metaboliseringen av fruktose er med andre ord ikke begrenset av tilgjengelig ATP. Fruktose påvirker proteiner (protein-1c) som er involvert i reguleringen av genuttrykket for hepatisk lipogenese (13). Det er også påvist at fruktose stimulerer endoteliale inflammatoriske prosesser via intercellulært adhesjonsmolekyl (ICAM-1) og hemmer produksjonen av endotelial nitrittoksidsyntase (14).

\section{Fruktsukker og metabolsk syndrom, hypertensjon og renal sykdom}

I dyreeksperimentelle studier medfører inntak av fruktose i fire uker høyere urinsyrenivåer i blod, nedsatt renal utskilling av urinsyre, høyere triglyseridnivåer, høyere fastende insulinnivåer, økt insulinproduksjon ved glukosetoleransetest og nedsatt insulinsensitivitetsindeks sammenliknet med inntak av glukose. Alle disse forskjellene utliknes ved inntak av xantinoksidasehemmeren allopurinol (15). Inntak av fruktose gir signifikant større progrediering av kronisk nyresvikt, større nyrer, glomerulær hypertrofi med fokal segmental sklerose og økt interstitiell fibrose sammenliknet med glukose (16).

Økt perifer insulinresistens kan forklares ved at urinsyre og/eller fruktose hemmer produksjonen av nitrittoksid og derfor ned- 


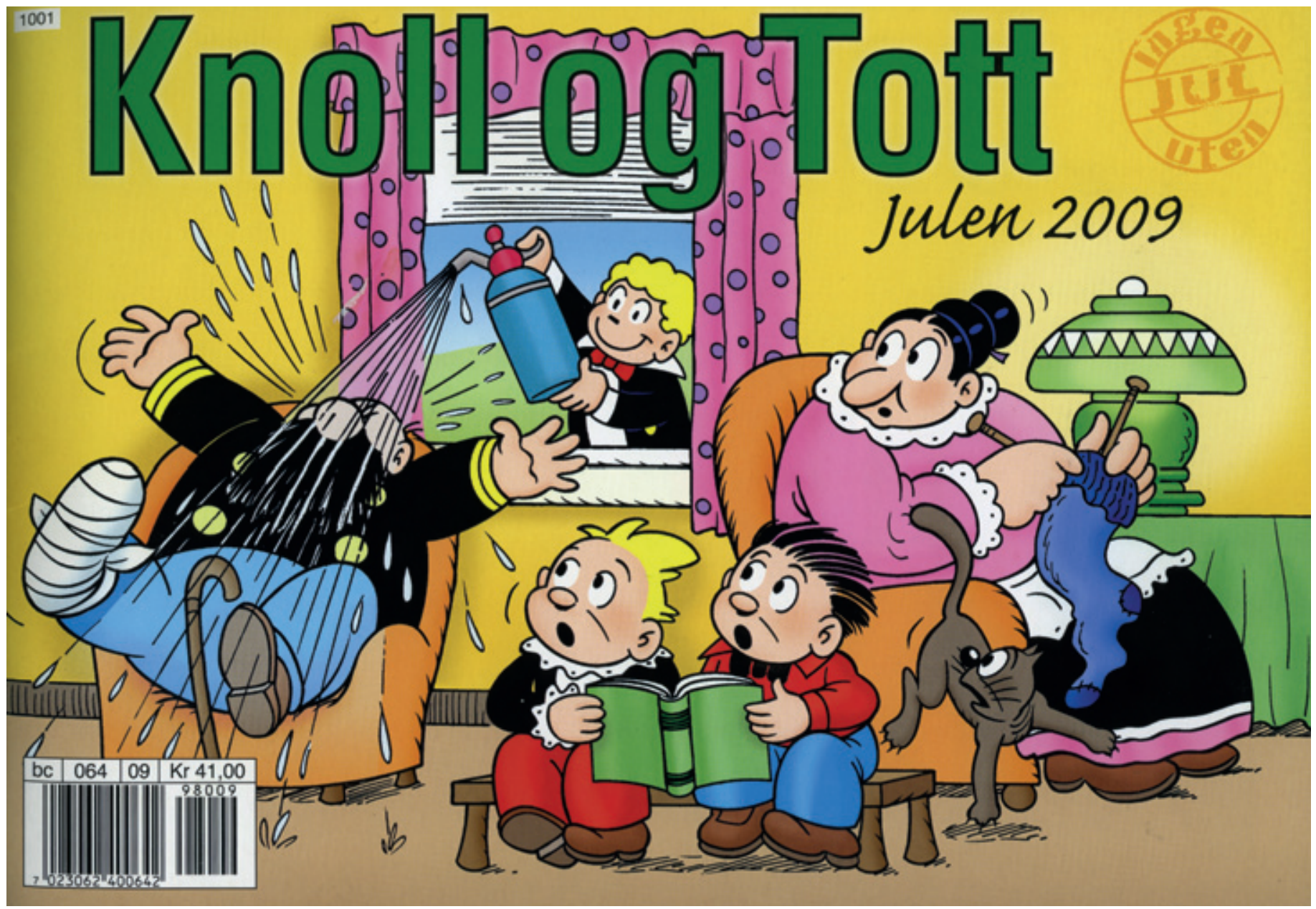

Kaptein Vom på forsiden av Knoll og Tott. @ KFS/Bulls

satt perifer sirkulasjon. Stimulert produksjon av MCP-1 og ICAM-1 kan forklare den renale effekten.

Glukosetoleransetest utført på voksne overvektige personer etter ni ukers forbehandling med ekvivalente mengder glukose eller fruktose, viser signifikant høyere glukose- og insulinverdier etter forutgående inntak av fruktose sammenliknet med glukose. Det samme gjelder leverens de novo lipogenese og abdominal fettavleiring (13).

Ved en oppfølging av over 46000 menn gjennom 12 år med selvrapportert kostanamnese fant man at inntak av sukkerholdige drikkevarer og fruktose, inklusive frukt og fruktjuice med høyt innhold av fruktose, var sterkt assosiert med økt risiko for podagra (17). En tverrsnittsstudie fra USA viste at inntak av $\geq 75 \mathrm{~g}$ fruktose daglig er uavhengig assosiert med høyere blodtrykk hos voksne (18). I en kontrollert intervensjonsstudie fikk voksne menn $200 \mathrm{~g}$ fruktose i 14 dager med eller uten tillegg av allopurinol. Begge gruppene utviklet funn forenlig med metabolsk syndrom, og allopurinol hadde en klar blodtrykksreduserende effekt (19).

\section{Urinsyre og kardiovaskulær risiko} Dyreeksperimentelt er det en lineær assosiasjon mellom urinsyrekonsentrasjonen i blod og acetylkolinmediert vasodilatasjon (15). Det samme er tilfellet hos friske voksne med normale urinsyreverdier (20). Hos voksne med ubehandlet ukomplisert hypertensjon er urinsyrekonsentrasjonen uavhengig og sterkere assosiert med endotel dysfunksjon enn hva systolisk blodtrykk og hyperlipidemi er (21).

Det er gjennomført flere studier for å påvise kausale sammenhenger av klinisk betydning mellom urinsyre, endotelfunksjon og sykdom (22-24). I en studie med 78 barn i alderen $8-13$ år hadde de med fødselsvekt $<2500 \mathrm{~g}$ høyere urinsyreverdier, dårligere endotelfunksjon og høyere systolisk blodtrykk enn dem med fødselsvekt $>3000 \mathrm{~g}$ (24). I en retrospektiv analyse av 125 personer i alderen 6-18 år henvist for hypertensjon hadde barn med essensiell hypertensjon lavere fødselsvekt. Det ble funnet en lineær assosiasjon mellom blodtrykksnivå og urinsyrenivå både hos dem med normalt og dem med forhøyet blodtrykk (23). Reduksjon av urinsyrenivået ved bruk av allopurinol ga lavere blodtrykk. Hypotesen om effekten av lavt antall nefroner ved lav fødselsvekt ble diskutert.

I en tverrsnittsundersøkelse med 1370 gutter og jenter i alderen 12-17 år fant man en lineær assosiasjon mellom kvartiler av urinsyrenivå og metabolsk syndrom og mellom urinsyrenivå og antall komponenter av metabolsk syndrom (25). I to ferske studier så man at allopurinol reduserte venstre ventrikkel-hypertrofi og endotelial dysfunksjon etter ni måneder hos pasienter med kronisk nyresvikt (Kao og medarbeidere, European Renal Association-European Dialysis and Transplant Association Congress, 27.6. 2010) og bedret koronar hypoksi etter seks uker vurdert ved elektrokardiografi og forekomst av brystsmerter (26).

\section{Urinsyre og renal risiko}

I flere store oppfølgingsstudier med flere tusen deltakere var urinsyrekonsentrasjonen ved start en uavhengig risikofaktor for nytilkommet nyresvikt $(27,28)$. I en kontrollert intervensjonsstudie i 12 måneder var progresjon av nyresvikt blant personer med hyperurikemi signifikant mindre ved bruk av allopurinol sammenliknet med kontrollgruppen (29).

\section{Inntak av fruktose}

Dyreeksperimentelle og kliniske studier gir et forvarsel om at fruktose har negative effekter på kardiovaskulær helse. Den kliniske betydningen er ikke avklart. Inntak av $>74 \mathrm{~g}$ fruktose har vist seg å være 
uavhengig assosiert med høyere blodtrykk (18). En metaanalyse av 14 randomiserte og ikke-randomiserte studier der fruktose erstattet sukrose, glukose og stivelse, viste usikre forskjeller i fastende $\mathrm{HbA} 1 \mathrm{c}-\mathrm{og}$ triglyserid-verdier (30). Forfatterne konkluderte med at i sammenlikning med stivelse er et fruktoseinntak på $>100 \mathrm{~g}$ daglig ugunstig (fruktoseinntaket blant voksne amerikanere er opp til $150 \mathrm{~g}$ daglig). Studiene er ulike, og resultatene er vanskelig å tolke.

\section{Konklusjon}

Ut ifra vitenskapelige studier er det grunn til å skjerpe den offentlige interessen for ernæringsmessig uheldige konsekvenser av høyt fruktoseinntak, spesielt som søtningsmiddel i ferdigprosesserte matvarer og drikker. Fruktose er - sammenliknet med glukose - et «tveegget sverd» som gir økt produksjon av både lipider og urinsyre. Barn og ungdom er mest utsatt.

Kaptein Vom hadde podagra, en klinisk følge av økt urinsyrenivå og indikasjon for intervensjon. Men kaptein Vom var også betydelig verre stilt med tanke på metabolsk syndrom, kardiovaskulær sykdom og kronisk nyresvikt, der urinsyre kan ha kausal betydning. Forebyggende urinsyrereduserende behandling burde vært igangsatt.

Oppgitte interessekonflikter: Ingen

\section{Litteratur}

1. Garrod A. Observations on the blood and urine of gout, rheumatism and Bright's disease. Med Chir Trans 1848; 31: 83

2. Mohamed F. On chronic Bright's disease, and its essential symptoms. Lancet 1879; 1: 399-401.

3. Graham I, Atar D, Borch-Johnsen K et al. European guidelines on cardiovascular disease prevention in clinical practice: executive summary. Fourth Joint Task Force of the European Society of Cardiology and Other Societies on Cardiovascular
Disease Prevention in Clinical Practice. Eur J Cardiovasc Prev Rehabil 2007; 14 (suppl 2): E1-40.

4. Talbott JH, Terplan KL. The kidney in gout. Medicine (Baltimore) 1960; 39: 405-67.

5. Breckenridge A. Hypertension and hyperuricaemia. Lancet 1966; 1: 15-8.

6. Wu XW, Muzny DM, Lee CC et al. Two independent mutational events in the loss of urate oxidase during hominoid evolution. J Mol Evol 1992: 34: $78-84$.

7. Oda M, Satta Y, Takenaka $O$ et al. Loss of urate oxidase activity in hominoids and its evolutionary implications. Mol Biol Evol 2002: 19: 640-53.

8. Heinig $M$, Johnson RJ. Role of uric acid in hypertension, renal disease, and metabolic syndrome. Cleve Clin J Med 2006; 73: 1059-64.

9. Johnson RJ, Segal MS, Sautin Y et al. Potensial role of sugar (fructose) in the epidemic of hypertension, obesity and the metabolic syndrome, diabetes, kidney disease, and cardiovascular disease. Am J Clin Nutr 2007; 86: 899-906.

10. Vos MB, Kimmons JE, Gillespie $C$ et al. Dietary fructose consumption among US children and adults: the third National Health and Nutrition Examination Survey. Medscape J Med 2008; 10: 160.

11. van den Berghe G. Fructose: Metabolism and short-term effects on carbohydrate and purine metabolic pathways. Prog Biochem Pharmacol 1986; $21: 1-32$

12. Cirillo P, Gersch MS, Mu W et al. Ketohexokinasedependent metabolism of fructose induces proinflammatory mediators in proximal tubular cells. J Am Soc Nephrol 2009; 20: 545-53.

13. Stanhope KL, Schwarz JM, Keim NL et al. Consuming fructose-sweetened, not glucose-sweetened, beverages increases visceral adiposity and lipids and decreases insulin sensitivity in overweight/obese humans. J Clin Invest 2009; 119: 1322-34.

14. Glushakova O, Kosugi T, Roncal $\mathrm{C}$ et al. Fructose induces the inflammatory molecule ICAM- 1 in endothelial cells. J Am Soc Nephrol 2008; 19: 1712-20.

15. Nakagawa T, Hu H, Zharikov $\mathrm{S}$ et al. A causal role of uric acid in fructose-induced metabolic syndrom. Am J Physiol Renal Physiol 2006; 290: F625-31

16. Gersch MS, Mu W, Cirillo P et al. Fructose, but no dextrose, accelerates the progression of chronic kidney disease. Am J Physiol Renal Physiol 2007; 293: F1256-61.

17. Choi HK, Curhan G. Soft drinks, fructose consumption, and the risk of gout in men: prospective cohort study. BMJ 2008; 336: 309-12.
18. Jalal DI, Smits G, Johnson RJ et al. Increased fructose associates with elevated blood pressure. J Am Soc Nephrol 2010; 21: 1543-9.

19. Perez-Pozo SE, Schold J, Nakagawa T el al. Excessive fructose intake induces the features of metabolic syndrome in healthy adult men: role of uric acid in the hypertensive response. Int J Obes 2010 34: $454-61$.

20. Erdogan D, Gullu H, Caliskan M et al. Relationship of uric acid to measures of endothelial function and atherosclerosis in healthy adults. Int J Clin Pract 2005; 59: 1276-82.

21. Zoccalli C, Maio R, Mallamaci F et al. Uric acid and endothelial dysfunction in essential hypertension. J Am Soc Nephrol 2006; 17: 1466-71

22. Feig DI, Johnson RJ. Hyperuricemi in childhood primary hypertension. Hypertension 2003; 42 247-52.

23. Feig DI, Nakagawa T, Karumanchi SA et al. Hypothesis: Uric acid, nephron number, and the pathogenesis of essential hypertension. Kidney Int 2004; 66: $281-7$.

24. Franco MC, Christofalo DM, Sawaya AL et al. Effect of low birth weight in 8- to 13-year-old children. Implications in endothelial function and uric acid level. Hypertension 2006; 48: 45-50.

25. Ford ES, Li C, Cook $S$ et al. Serum concentrations of uric acid and the metabolic syndrome among US children and adolescents. Circulation 2007; 115: 2526-32

26. Noman A, Ang DS, Ogston S et al. Effect of highdose allopurinol on exercise in patients with chronic stable angina: a randomised, placebo controlled crossover trial. Lancet 2010; 375: 2161-7.

27. Obermayr RP, Temml C, Gutjahr G et al. Elevated uric acid increases the risk for kidney disease. J Am Soc Nephrol 2008; 19: 2407-13.

28. Weiner DE, Tighiouart H, Elsayed EF et al. Uric acid and incident kidney disease in the community. J Am Soc Nephrol 2008; 19: 1204-11.

29. Siu Y-P, Leung K-T, Tong MK et al. Use of allopurinol in slowing the progression of renal disease through its ability to lower uric acid level. Am J Kidney Dis 2006; 47: 51 -9.

30. Livesy G, Taylor R. Fructose consumption and consequences for glycation, plasma triacylglycerol. and body weight: meta-analyses and meta-regression models of intervention studies. Am J Clin Nutr 2008; 88: 1419-37.

Mottatt 5.7. 2010, første revisjon innsendt

7.10. 2010, godkjent 4.11. 2010.

Medisinsk redaktør Petter Gjersvik. 